\title{
Contamination of Red Sea Shrimp (Palaemon serratus) with Polycyclic Aromatic Hydrocarbons: a Health Risk Assessment Study
}

\author{
Rim A. Hussein ${ }^{1 *}$, Khalid A. Al-Ghanim², Magda M. Abd-El-Atty ${ }^{1}$, \\ Laila A. Mohamed ${ }^{3}$ \\ ${ }^{1}$ Environmental Health Department, High Institute of Public Health, Alexandria University, \\ Egypt \\ ${ }^{2}$ Department of Zoology, College of Science, King Saud University, \\ Saudi Arabia \\ ${ }^{3}$ Marine Chemistry Lab, Environmental Division, National Institute of Oceanography and Fisheries, \\ Egypt
}

Received: 6 June 2015

Accepted: 26 November 2015

\begin{abstract}
The aquatic environment of the Red Sea is facing many threats resulting from land-based activities.

The aim of the present study was to measure the concentrations of polycyclic aromatic hydrocarbons (PAHs) in Red Sea shrimp and to assess the health risk resulting from their consumption.

Gas chromatography/flame ionization detection was used for PAH detection.

Polycyclic aromatic hydrocarbons exceeded the maximum residue levels authorized in crustaceans. They were found to be of pyrogenic source, and their total toxicity equivalent concentration was $0.03078 \mu \mathrm{g} \mathrm{g}^{-1}$. Assessment of cancer risk resulting from consumption of polycyclic aromatic hydrocarboncontaminated shrimp proved that the U.S. Environmental Protection Agency risk goal of $10^{-6}$ has been exceeded. Continuous monitoring programs for air, water, and sediment quality are therefore recommended.
\end{abstract}

Keywords: health risk assessment, PAHs, Red Sea, shrimp

\section{Introduction}

The aquatic environment of the Red Sea faces many threats resulting from land-based activities. It is surrounded by many countries, including Egypt, Jordan, Saudi

*e-mail: rimahamid@yahoo.com
Arabia, Yemen, and Sudan. In these countries, coastal developmental activities such as harbors and touristic villages, and industrial activities such as oil refineries, power plants, and desalination plants are continuously increasing. Besides, some agricultural activities involving the use of pesticides and insecticides are also going on. All these activities result in the generation of solid waste, 
wastewater, and air pollutants that may have an adverse impact on the aquatic flora and fauna of the sea [1].

Measurable concentrations of polycyclic aromatic hydrocarbons (PAHs) have been detected in both sediment samples and edible portions of fish collected from Egyptian and Yemeni Red Sea coasts, respectively [2, 3]. PAHs are considered persistent organic pollutants (POPs). They are characterized by their resistance to photolytic, biological, and chemical degradation, their semi-volatility, and long range transport, bioaccumulation in fatty tissue, and biomagnifications in food chains. They are considered endocrine disruptors, can adversely affect reproductive and immune systems, and induce or promote cancer as well [4].

To the best of our knowledge, PAH concentrations in shrimp collected from the Red Sea has not been investigated. Therefore, the aim of our study was to measure the concentrations of PAHs in Red Sea shrimp and to assess the health risk resulting from their consumption.

\section{Materials and Methods}

PAHs were analyzed following the method described by El-Agroudy et al. [5].

\section{Standards and Reagents}

A stock solution containing the following PAHs was used: naphthalene, acenaphthylene, acenaphthene, fluorene, phenanthrene, anthracene, fluoranthene, benzo(a) pyrene, benzo(b)fluoranthene, benzo(k)fluoranthene, benzo(a)anthracene, chrysene, pyrene, dibenzo(a,h) anthracene, benzo(g,h,i)perylene, and indeno( $(1,2,3, \mathrm{~cd})$ pyrene. A series of calibration standards was created by dilution at $0.1,0.25,0.5,0.75,1.0,2.0,5.0$, and $10 \mu \mathrm{g} / \mathrm{mL}$.

\section{Sample Preparation}

A 30 gm portion of the shrimp sample was mixed with $90 \mathrm{~g}$ anhydrous sodium sulphate, and immersed in an ultrasonic bath with $2 \times 100 \mathrm{~mL}$-hexane for 30 min twice, followed by a third extraction with $100 \mathrm{~mL}$ dichloromethane. The three extracts were combined and desulfurized through activated cupper powder; then concentrated in a rotary evaporator at $35^{\circ} \mathrm{C}$, followed by a concentration with nitrogen gas stream down to a volume of $2 \mathrm{~mL}$.

\section{Sample Clean up and Fractionation}

This was achieved prior to the gas chromatographflame ionization detector (GC/FID). The first $\mathrm{mL}$ of the extracted volume was passed through a silica column prepared by slurry packing of $20 \mathrm{~mL}(10 \mathrm{~g})$ silica, followed by $10 \mathrm{~mL}(10 \mathrm{~g})$ alumina, and finally $1 \mathrm{~g}$ anhydrous sodium sulfate. Elution was performed using $40 \mathrm{~mL}$ n-hexane/ dichloromethane (90:10) followed by $20 \mathrm{~mL}$ n-hexane/ dichloromethane (50:50). Finally, eluted samples were concentrated under a gentle stream of purified nitrogen to about $0.2 \mathrm{~mL}$ prior to injection into GC/FID.

\section{Instrument}

Samples were analyzed in a Hewlett Packard 5890 series II GC/FID. The instrument was operated in splitless mode (3 $\mu \mathrm{L}$ splitless injection) with the injection port maintained at $290^{\circ} \mathrm{C}$, and the detector maintained at $300^{\circ} \mathrm{C}$. Samples were analyzed on a fused silica capillary column HP-1, 100\% dimethyl polysiloxane (30 m length, $0.32 \mathrm{~mm}$ id, $0.17 \mu \mathrm{m}$ film thickness). The oven temperature was programmed from $60^{\circ} \mathrm{C}$ to $290^{\circ} \mathrm{C}$, increasing at a rate of $3^{\circ} \mathrm{C} / \mathrm{min}$, and held at $290^{\circ} \mathrm{C}$ for $25 \mathrm{~min}$. The carrier gas was nitrogen flowing at a rate of $1.2 \mathrm{~mL} / \mathrm{min}$.

\section{Quality Control}

For analytical reliability and recovery efficiency of the results, six analyses were carried out on PAH reference materials HS-5 and 2974 (provided by EIMP-IAEA). Laboratory results showed a recovery efficiency ranging between $92 \%$ and $111 \%$, with $8-14 \%$ coefficient of variation for the 16 studied PAH fractions. The detection limit was $0.01 \mu \mathrm{g} / \mathrm{mL}$ for each PAH.

\section{Health Risk Assessment}

Cancer risk was assessed according to Eq. 1 [6]:

\section{Cancer risk \\ $=($ Slope factor $)($ Chronic daily intake $)$}

Slope factor is obtained from the integrated risk information system (USEPA, IRIS) [7] and chronic daily intake is calculated according to Eq. 2 ( $\mathrm{mg} / \mathrm{kg}$.day):

$=$ Average daily dose (mg/day) / body weight (Kg)

Average daily dose is calculated according to Eq. 3:

$=($ Concentration of contaminant, $\mathrm{mg} / \mathrm{Kg})($ per capita consumption of fish and shellfish, $\mathrm{Kg}$ /day)

... and body weight is taken as $60 \mathrm{Kg}$ for an adult.

If the risk is higher than the EPA acceptable level of $10^{-6}$, consumption of shrimp will not be acceptable from a cancer risk standpoint.

\section{Results and Discussion}

The high-molecular-weight PAHs originate mainly from vehicle exhaust, while the lower weight ones are generated from low-temperature incomplete burning of 
Table 1. Mean concentration ( $\left.\mu \mathrm{g} \mathrm{g}^{-1}\right)$, percentage, and maximum residue level $\left(\mu \mathrm{gg}^{-1}\right)$ of some PAHs in shrimp collected from the Red Sea (2014).

\begin{tabular}{|c|c|c|c|}
\hline PAHs & Mean $\pm \mathrm{SD}$ & $\%$ within total PAHs & Maximum level \\
\hline Acenaphthene & $0.0422 \pm 0.0001$ & 10.5 & $\mathrm{ND} *$ \\
\hline Acenaphthylene & $0.0137 \pm 0.0001$ & 3.4 & $\mathrm{ND} *$ \\
\hline Anthracene & $0.006 \pm 0.0003$ & 1.4 & $\mathrm{ND} *$ \\
\hline Benzo(a)pyrene.. & $0.007 \pm 0.0002$ & 1.6 & \multirow{4}{*}{$\begin{array}{c}0.002 \mathrm{BaP} * * \\
0.012 \mathrm{PAH} 4 * *\end{array}$} \\
\hline Benzo(a)anthracene.. & $0.102 \pm 0.004$ & 25.2 & \\
\hline Benzo(a)phenanthrene (Chrysene) & $0.006 \pm 0.0001$ & 1.4 & \\
\hline Benzo(b)fluoranthene.. & $0.002 \pm 0.0001$ & 0.5 & \\
\hline Benzo(k)fluoranthene & $0.0012 \pm 0.0001$ & 0.3 & ND * \\
\hline Benzo(g,h,i)perylene & $0.003 \pm 0.0003$ & 0.8 & ND * \\
\hline Dibenzo (a,h)anthracene & $0.086 \pm 0.002$ & 21.3 & ND * \\
\hline Fluoranthene & $0.043 \pm 0.001$ & 10.6 & ND * \\
\hline Fluorene & $0.023 \pm 0.0001$ & 5.6 & ND * \\
\hline Indeno( $1,2,3)$ pyrene & $0.046 \pm 0.003$ & 11.4 & $\mathrm{ND} *$ \\
\hline Naphthalene & $0.014 \pm 0.001$ & 3.5 & $\mathrm{ND} *$ \\
\hline Phenanthrene & $0.005 \pm 0.0001$ & 1.3 & ND * \\
\hline Pyrene & $0.0054 \pm 0.0004$ & 1.4 & ND * \\
\hline Total PAH & $0.403 \pm 0.013$ & & ND $*$ \\
\hline
\end{tabular}

* ND $=$ limit not determined for crustaceans in any national or international standard

** EU Commission [11].

coal, oil, gas, and garbage, and spillage from ships and boats [8]. Our study revealed that total PAH detected in shrimp was $0.4 \mu \mathrm{g} \mathrm{g}^{-1}$ (Table 1). About half of this concentration was anthracene, both as benzo(a) anthacene (25\%) and dibenzo $(\mathrm{a}, \mathrm{h})$ anthracene $(21 \%)$. Some PAHs listed on the EPA priority chemical list [9] were also detected in the collected shrimps. Examples include acenaphthene $(10.5 \%)$, acenaphthylene (3.4\%), anthracene $(1.4 \%)$, benzo $(\mathrm{g}, \mathrm{h}, \mathrm{i})$ perylene $(0.8 \%)$, phenanthrene $(1.3 \%)$, and pyrene $(1.4 \%)$.

In order to protect public health, maximum levels are set for PAHs in certain fatty foods and in foods subjected to smoking processes. Maximum levels are set as well in foods affected by environmental pollution such as fish and fishery products that might be exposed to PAHs from oil spills caused by shipping [10]. Until 2008, the EU Scientific Committee on Food was considering benzo[a]pyrene as the only marker for the occurrence of PAH in food, and was giving it a maximum level of $5 \mu \mathrm{g} \mathrm{kg}^{-1}$ wet weight. In 2008 the European Food Safety Authority (EFSA) suggested a total concentration of four PAHs (benzo[a] pyrene, benz[a]anthracene, benzo[b]fluoranthene and chrysene) as a better indicator for the occurrence of PAH in food while keeping the maximum level for benzo(a) pyrene as a standard to allow the comparison between previous and future data. Therefore, EU regulation No. $835 / 2011$ published maximum levels for the so-called
PAH4 (sum of the four substances) in addition to the maximum level for benzo[a]pyrene $\left(30 \mu \mathrm{g} \mathrm{Kg}{ }^{-1}\right.$, and $5 \mu \mathrm{g}$ $\mathrm{Kg}^{-1}$, respectively). Starting from 1 September 2014, these two levels have been reduced to $12 \mu \mathrm{g} \mathrm{Kg}^{-1}$ for PAH4 and $2 \mu \mathrm{g} \mathrm{Kg}^{-1}$ for benzo[a]pyrene [11].

Accordingly, shrimp samples collected for the study were found to be heavily polluted with PAHs because of exceeding both the MRL for benzo[a]pyrene 3.5-fold and that of PAH4 10-fold (Table 1). This could be due to fossil fuel combustion for various industrial activities, some oil spills from ships, and proximity to petrol work sites. This was in accordance with results revealed by a recent study performed on Red Sea sediment, which reported total PAHs to range between 0.74 and $456 \mathrm{ng}$ g-1, with a mean value of $33 \mathrm{ng}$ g-1 [12]. Ten years ago research carried out on hydrocarbon levels in mussels from the Red Sea revealed an average PAH concentration of $5452 \mathrm{ng}$ g-1, a figure 10-fold higher than that in shrimp collected for the present study [13]. This could be due to different bioconcentration factors between mussels and shrimp.

In Estero de Urias, Mexico, values comparative to ours were obtained: total PAH was measured in shrimp and was found to range from 0.036 to $0.5 \mu \mathrm{g} g-1$. However, in the Mexico study phenanthrene was the predominant PAH congener $(25 \%)$ detected, followed by pyrene and fluorine [14]. In Aliağa Bay, Turkey, sediments were found to be polluted with toxic PAH compounds, and this has been 
Table 2. Toxicity Equivalence Factors (TEFs) and Total Toxicity Equivalent Concentrations (TTECs) for PAH mixture detected in shrimp collected from the Red Sea (2014).

\begin{tabular}{|c|c|c|c|}
\hline PAH congener & Concentration, $\mu \mathrm{g} g-1$ & TEF (unitless) & Toxicity Equivalent Concentration, $\mu \mathrm{g}$ g-1 \\
\hline Benzo(a)pyrene & 0.007 & 1 & 0.007 \\
\hline Benzo(a)anthracene & 0.102 & 0.1 & 0.0102 \\
\hline Benzo(b)fluoranthene & 0.002 & 0.1 & 0.0002 \\
\hline Benzo(k)fluoranthene & 0.0012 & 0.1 & 0.00012 \\
\hline Chrysene & 0.006 & 0.01 & 0.00006 \\
\hline Dibenzo(a,h)anthracene & 0.086 & 0.1 & 0.0086 \\
\hline Indeno(1,2,3cd)pyrene & 0.046 & 0.1 & 0.0046 \\
\hline Total & & & 0.03078 \\
\hline
\end{tabular}

attributed to the activities going on in the bay, including ship breaking, plus steel and petrochemical industries [15]. Polycyclic Aromatic Hydrocarbons (PAHs) were also detected in sediments of the Cotonou coastal zones (Benin) and in Aquitaine sediment samples (France). Such contamination was mainly in harbors due to waste oils from workshops, transport of petroleum products, and air pollution resulting from combustion of fossil fuel in ships [16].

\section{Health Risk Assessment}

In addition to their presence in high concentrations, $64 \%$ of the total PAHs consisted of compounds that are suspected human carcinogens. Benzo[a]pyrene $(\mathrm{BaP})$, benz[a]anthracene $(\mathrm{BaA})$, benzo[b]fluoranthene $(\mathrm{BbF})$, benzo[k]fluoranthene $(\mathrm{BkF})$, dibenzo $(\mathrm{a}, \mathrm{h})$ anthracene (DBA), and indeno $(1,2,3)$ pyrene (InP) are probable human carcinogens (B2), while naphthalene is possibly one (C) [17]. Among these substances, only benzo[a] pyrene has a pre-determined oral slope factor of 7.3 $\left(\mathrm{mg} \mathrm{kg} \mathrm{kg}^{-1}\right)^{-1}$, to be used for health risk assessment [7]. Consequently, the USEPA has established toxicity equivalency factors (TEFs) for some PAH congeners to estimate their relative carcinogenicity compared to $\mathrm{BaP}$ as a reference substance. These estimates are recommended to be adopted only when exposure is from the oral route [18]. TEFs for BaP, BaA, BbF, BkF, Chr, DBA, and InP are $1,0.1,0.1,0.1,0.01,0.1$, and 0.1 , respectively. Hence the total toxicity equivalent concentration (TTEC) of PAHs can be calculated according to Eq. 4 [19]:

Total toxicity equivalent concentration

$$
=\sum \mathrm{Cn} \text {. TEFn }
$$

... where $\mathrm{Cn}$ is the concentration of the individual congener $\mathrm{n}$ in PAH mixture and TEFn is the toxicity equivalency factor for the individual congener $n$.

From Table 2 it is clear that the TTEC of PAHs from our analysis was $0.03078 \mu \mathrm{g} \mathrm{g}^{-1}$. This value was in accordance with that revealed by a recent study conducted on Red Sea sediment that reported TTEC to range between $\mathrm{ND}$ and $72.27 \mathrm{ng} \mathrm{g}^{-1}$ [12].

Using the TTEC as concentration of the contaminant in equation (3), carcinogenic risk resulting from consumption of shrimp polluted with PAHs could be calculated for consumers living in countries surrounding the Red Sea, based on the per capita consumption of fish and shellfish in these countries (2007-09 average) [20]. This risk is illustrated in Table 3 and Fig. 1. It was obvious that it exceeded the EPA risk goal of $10^{-6}$ in Egypt, Sudan,

Table 3. Cancer risk resulting from ingesting shrimp contaminated with PAHs in countries surrounding the Red Sea, 2014.

\begin{tabular}{|c|c|c|c|c|c|c|}
\hline \multirow{2}{*}{ Country } & \multicolumn{2}{|c|}{ per capita consumption* } & \multirow{2}{*}{ TTEC, mg/Kg } & \multirow{2}{*}{$\begin{array}{c}\text { Average daily intake, } \\
\text { mg/day }\end{array}$} & \multirow{2}{*}{$\begin{array}{c}\text { Chronic daily intake, } \\
\text { mg/kg.day }\end{array}$} & \multirow{2}{*}{$\begin{array}{c}\text { Cancer risk } \\
* *\end{array}$} \\
\hline & $\mathrm{Kg} /$ year & $\mathrm{Kg} /$ day & & & & \\
\hline Egypt & 17.5 & 0.0479 & 0.03078 & 0.001475753 & $2.459 \mathrm{E}-05$ & $179.55 \mathrm{E}-06$ \\
\hline Sudan & 1.8 & 0.0049 & 0.03078 & 0.000151792 & $2.529 \mathrm{E}-06$ & $18.468 \mathrm{E}-06$ \\
\hline Yemen & 3 & 0.0082 & 0.03078 & 0.000252986 & $4.216 \mathrm{E}-06$ & $30.78 \mathrm{E}-06$ \\
\hline $\begin{array}{c}\text { Saudi } \\
\text { Arabia }\end{array}$ & 9 & 0.02466 & 0.03078 & 0.000758959 & $1.265 \mathrm{E}-05$ & $92.34 \mathrm{E}-06$ \\
\hline Jordan & 6.8 & 0.0186 & 0.03078 & 0.000573436 & $9.557 \mathrm{E}-06$ & $69.768 \mathrm{E}-06$ \\
\hline
\end{tabular}

*FAO [20]

** From Eq. 1, cancer risk $=$ chronic daily intake $\mathrm{X}$ slope factor which is $7.3\left(\mathrm{mg} \mathrm{kg}^{-1} \mathrm{~d}^{-1}\right)-1$ 


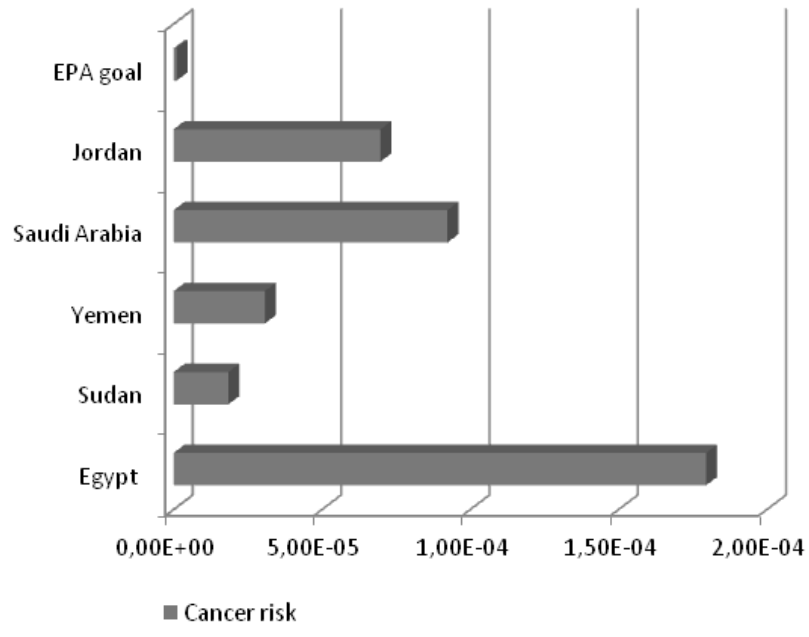

Fig. 1. Cancer risk resulting from ingestion of shrimp contaminated with PAHs in countries surrounding the Red Sea, compared with EPA $10^{-6}$ goal (2014).

Yemen, Saudi Arabia, and Jordan, indicating a cancer risk that may result from the consumption of the contaminated shrimp.

In order to recommend preventive measures for such pollution, the origin of PAHs has to be determined. The molecular diagnostic ratio was used for this purpose. It enables us to differentiate between petrogenic and pyrogenic sources of PAHs based on the ratio of some substances relative to each other: If Fluo/Fluo $+\mathrm{Pyr}<0.4$ and Inp/Inp + BghiP $<0.2$, this will give an indication of a petrogenic $\mathrm{PAH}$ source. If both ratios are greater than 0.5 , this will imply a pyrogenic PAH source resulting from combustion of coal and biomass. If the first ratio is $0.4-0.5$ and the latter is $0.2-0.5$, this will be concerning liquid fossil fuel combustion [21]. It was clear from Table 1 that PAH present in shrimp was from coal combustion since each of Fluo/Fluo+Pyr and Inp/Inp+BghiP $=0.9$. This was in accordance with the study carried out on Red Sea sediment that reported PAHs in sediment to be from a pyrogenic source [12].

\section{Conclusion and Recommendation}

The concentration of polycyclic aromatic hydrocarbons in shrimp (Palaemon serratus) collected from the Red Sea was investigated. It exceeded the permissible levels in crustaceans. Detected PAHs were found to be of pyrogenic source. Assessment of cancer risk resulting from consumption of PAH-contaminated shrimp proved that the EPA risk goal of $10^{-6}$ has been exceeded.

It is therefore recommended to carry out a continuous monitoring program for air, water, and sediment quality, and to install filters in stacks of industrial plants and ships in order to reduce air pollution resulting from coal combustion, to prevent fishing in areas nearby shipping and industrial activities, and in the long term to shift to cleaner forms of energy production.

\section{Acknowledgements}

The authors would like to express their sincere appreciation to the Deanship of Scientific Research at King Saud University for its funding of this research through the Research Group Project No. RGP-1436-11.

\section{References}

1. UNEP/PERSGA: Assessment of Land-based Sources and Activities Affecting the Marine Environment in the Red Sea and Gulf of Aden. UNEP Regional Seas Reports and Studies No. 166, UNEP, 1997.

2. EL-NEMR A., EL-SADAAWY M., KHALED A., ELSIKAILY A. Distribution patterns and risks posed of polycyclic aromatic hydrocarbons contaminated in the surface sediment of the Red Sea coast (Egypt). Desalination and Water Treatment 52, 7964, 2014.

3. DOU-ABUL A., HEBA H., FAREED K. Polynuclear aromatic hydrocarbons (PAHs) in fish from the Red Sea Coast of Yemen. Hydrobiology 123, 251, 1997.

4. RITTER L., SOLOMON K., FORGET J., STEMEROFF M., O'LEARY C. A review of selected persistent organic pollutants. International Programme on Chemical Safety 145, 1995.

5. EL-AGROUDY N., ABDEL-AZIM H., SOLIMAN Y., SAID T., EL-MOSELHY K. Concentrations of petroleum hydrocarbons in water and some marine organisms of the Gulf of Suez. Egyptian Journal of Aquatic Reseach 33, 2007.

6. MASTERS G. Introduction to Environmental Engineering and Science. $2^{\text {nd }}$ Ed. Prentice-Hall International Inc.: Toronto, 139, 1990.

7. USEPA. Integrated Risk Information System (IRIS). Available@ @ http://www.epa.gov/iris/ (accessed January 2015).

8. MAI B., QI S., ZENG E., YANG Q., ZHANG G., FU J., SHENG G., PENG P., WANG Z. Distribution of polycyclic aromatic hydrocarbons in the coastal region off Macao, China: assessment of input sources and transport pathways using compositional analysis. Environ Sci Technol, 37, 4855,2003

9. United States Environmental Protection Agency, Office of Solid Waste. Polycyclic Aromatic Hydrocarbons. EPA, Washington, DC 20460, January 2008.

10. Commission Regulation (EC) No 1881/2006 of 19 December 2006. Setting maximum levels for certain contaminants in foodstuffs. Available @ https://www.fsai.ie/uploadedFiles/ Consol_Reg1881_2006.pdf, (accessed January 2015).

11. European Commission. Commission Regulation (EU) No 835/2011 of 19 August 2011 amending regulation (EC) no $1881 / 2006$ as regards maximum levels for polycyclic aromatic hydrocarbons in foodstuffs. Off $\mathrm{J}$ Eur Union 2011;L 215:4. Available@http://eur-lex.europa.eu/legalcontent/EN/TXT/?uri=CELEX:32011R0835, (accessed January 2015).

12. SALEM D., MORSY F., EL-NEMR A., EL-SIKAILY A., KHALED A. The monitoring and risk assessment of aliphatic and aromatic hydrocarbons in sediments of the Red Sea, Egypt. The Egyptian Journal of Aquatic Research. In press. Available online 19 Dec. 2014.

13. EL-NEMR A., EL-SIKAILY A., KHALED A., SAID T., ABD-ALLA A. Determination of hydrocarbons in mussels from the Egyptian Red Sea Coast. Environmental Monitoring and Assessment, 96 (1-3), 251, 2004. 
14. JAWARD F., ALEGRIA H., REYES J., HOARE A. Levels of PAHs in the waters, sediments, and shrimps of Estero de Urias, an estuary in Mexico, and their toxicological effects. The Scientific World Journal, 2012, Article ID: 687034. doi: $10.1100 / 2012 / 687034$

15. NESER G., KONTAS A., UNSALAN D., ALTAY O., DARILMAZ E., ULUTURHAN E., KUCUKSEZGIN F., TEKOGUL N., YERCAN F. Polycyclic aromatic and aliphatic hydrocarbons pollution at the coast of Aliağa (Turkey) ship recycling zone. Mar Pollut Bull 64 (5), 1055, 2012.

16. SOCLO H., GARRIGUES P., EWALD M. Origin of Polycyclic Aromatic Hydrocarbons (PAHs) in Coastal Marine Sediments: Case Studies in Cotonou (Benin) and Aquitaine (France) Areas. Marine Pollution Bulletin 40 (5), 387, 2000.

17. RUBAILO A., OBERENKO A. Polycyclic aromatic hydrocarbons as priority pollutants. Journal of Siberian Federal University. Chemistry 4 (1), 344, 2008.
18. SCHOENY R., POIRIER K. Provisional Guidance for Quantitative Risk Assessment of Polycyclic Aromatic Hydrocarbons. U.S. Environmental Protection Agency, Office of Research and Development, Office of Health and Environmental Assessment, Washington, DC, EPA/600/R-93/089 (NTIS PB94116571).

19. Department of Ecology. State of Washington. Evaluating the toxicity and assessing the carcinogenic risk of environmental mixtures using toxicity equivalency factors. Available (a) https://fortress.wa.gov/ecy/clarc/FocusSheets/tef.pdf, (accessed January 2015).

20. Food and Agriculture Organization of the United Nations (FAO).Available @ http://www.st.nmfs.noaa.gov/st1/fus/ fus11/08_percapita2011.pdf, (accessed January 2015).

21. GUO J., WU F., ZHANG L., LIAO H., ZHANG R., LI W., ZHAO X., CHEN S., MAI B. Screening Level of PAHs in Sediment Core from Lake Hongfeng, Southwest China. Arch Environ Contam Toxicol. 60 (4), 590, 2011. 